\title{
Strengthening Social Capital to Enhance Participation In Public Sector
}

\author{
Hasniati $^{1}$, Rabina Yunus ${ }^{2}$, Nurlinah $^{3}$ and Sakaria ${ }^{4}$ \\ ${ }^{1}$ Faculty of Social and Political Science, Hasanuddin University \\ (Makassar, Indonesia) \\ ${ }^{2}$ Faculty of Social and Political Science, Hasanuddin University \\ (Makassar, Indonesia) \\ ${ }^{3}$ Faculty of Social and Political Science, Hasanuddin University \\ (Makassar, Indonesia) \\ ${ }^{4}$ Faculty of Social and Political Science, Hasanuddin University \\ (Makassar, Indonesia) \\ * Corresponding Author Hasniati,email: hasniati [AT] unhas.ac.id
}

\begin{abstract}
At the end of the 20th century, there was a significant movement to increase public participation in policy formulation, implementation and evaluation in developing countries. Participation keeps community life vital and public institutions to be accountable. When people feel that their participation in development has important value, the quality, effectiveness and efficiency of development will be increased. Therefore, the government should concern to promote public participation in the development program that can be enhance accountability This research was conducted in the coastal villages Takalar District South Sulawesi, Indonesia, using a case study approach with a qualitative descriptive analysis method. This research was explore social capital can enhance coastal communities participation in public fund management. By using in-depth interviews and focus group discussions, the study found that strategies that can be used by the government to increase community participation is to strengthening social capital in the community.
\end{abstract}

Keywords - Social capital strengthening, Participation, Accountability, Village fund management

\section{INTRODUCTION}

Poverty is one of the problems most common in developing countries. The quality of governance is critical to poverty reduction. Good governance facilitates participatory, pro-poor policy as well as sound macroeconomic management. It ensures the transparent use of public funds (Malvicini and Sweetser, 1999). In recognition of the importance of good governance for sustained economic in Asia and the Pacific, ADB adopted, in October 1995, a policy on governance that identified four means to sustained economic development: accountability, participation, predictability, and transparent. Since 1995, ADB has engaged in a-variety of country-based and sub-regional technical assistance activities to disseminate international experience in governance and public management. And through loans, has supported several governance reforms programs adopt by the government of its developing member countries (DMCs), such as the Indonesian government.

The Indonesian government has introduced a policy of Village Funds since 2014 through Government Regulation No. 60 of 2014 on Village Fund from the Indonesian Budget. The village fund to finance priority community development and empowerment. Effective development requires the involvement and real at the beginning of all stakeholders in the drafting of the activities that will affect them. When the people involved feel that their participation is important, the quality, effectiveness and efficiency of development initiatives will increase (Brinkerhoff and Crosby, 2002). In addition, for more than a decade ago there was general agreement that they are influenced by development initiatives have a right to participate in it. Thus, there is a pragmatic and moral justification to implement participatory approaches in designing development programs. More effective forms of participation is direct citizen participation. Because direct citizen participation most often rests on the shoulders of public administrators for successful execution, it is important to know how the citizen and his or her direct involvement are viewed within a particular framework (Roberts, 2004). 
The involvement of citizens in the planning and implementation of development programs will increase the sense of ownership of development programs. All this helps the smooth implementation of effective projects, monitoring of activities fair and sustainable results. Effective poverty reduction also requires greater flexibility in responding to problems and unexpected opportunities throughout the development, implementation and monitoring of projects. Sensitivity and collaboration among its intended beneficiaries, government, civil society, and the private sector at the regional level, intermediate (district, province, etc.), And national boost social capital development and sound governance (Malvicini and Sweetser, 1999).

That the new governance involves not simply tools but also practices and processes for people to participate in the work of government. Bingham, at all (2005: 548) argues that public managers ought to facilitate greater citizen engagement in the work of government. They assess the existing legal infrastructure authorizing public managers to use new governance processes. With a new governance, accountability of government programs would be better. In this article, we maintain that social capital owned coastal communities, which can be built by the government to support the implementation of the village fund program.

\section{BACKGROUND}

In the view of economics, capital is everything that can benefit or produce. Capital itself can be divided into (1) of capital in the form of material like money, buildings or goods; (2) the cultural capital in the form of educational quality; cultural wisdom; and (3) social capital in the form of togetherness, social obligations that were institutionalized in the form of common life, role, authority, responsibility, reward systems and other attachments that generate collective action. Social capital is the adhesive for each individual, in the form of norms, beliefs and nets work, resulting in mutually beneficial cooperation to achieve common goals. Social capital is also understood as knowledge and understanding shared by the community, as well as patterns of relationship that allows a group of individuals perform a productive activity. Social capital refers to the parts of the social-networking organization, norms of mutual dependence and trust-that facilitate cooperation for mutual benefit (Putnam, 1993).

Meanwhile, Pratikno et al (2001) distinguishes social capital on three levels, namely; values, institutions and mechanisms. Value consists of sympathy, a sense of duty, a sense of trust, reciprocity and mutual recognition. Institutions include public involvement as a citizen (civic engagement), associations and networks. The mechanism includes cooperation and synergy among group. Woolcock (2001) also distinguishes three types social capital, namely: (1) bounding social capital, (2) bridging social capital; (3) linking social capital. The types of social capital of work depending on the circumstances. He can work in weakness and wasting in a society. It can also be used and serve at once supporting inhibitors in social bonding so it depends how individuals and communities interpret.

Binding social capital, a social capital binding members of the public in a particular group, can be a value, culture, perceptions and traditions or customs. Binding social capital is characterized by a strong bind (linkage) as between family members or between members of certain ethnic groups. Some views equate this with thick bond of trust that social capital is awakened by a sense of trust among the group of people who know each other.

Bridging social capital (connect), is a form of social capital linking citizens from different social groups. Social capital of this type could arise due to various weaknesses, so decided to build a force from outside himself. While linking social capital (hook), a bond between a group of people who are weak and less powerful, with citizen groups holding power (powerful people).

Noting the various definitions that have been introduced in the above it can be concluded that social capital is a social investment, which includes social resources such as networks, beliefs, values and norms and strength moves (social participation, cooperation, reciprocity and tolerance), the structure of social relations to achieve individual objectives and/or groups efficiently and effectively with the other capital. From this formula, it can simply be understood that social capital is a social investment in the structure of social relations to achieve the expected goals.

\section{RESEACRH METHOD}

This research was conducted in the coastal villages Takalar District South Sulawesi. This study used a qualitative approach, appropriate to the exploratory nature of the investigation. The research was guided by interview guidelines (Weiss, 1995) to answer questions: (a) what form of community participation in management of village fund, and (b) how strategies to increase community participation in the management of village fund.

The data were collected in following way: 
- Semi structured interviews with policy makers from village government agencies that managed vilige fund programs used as case studies in our research.

- In-depth interviews with practitioners - citizens, village consultative bodies, program coordinators and managers of agencies implementing the village fund programs.

The interviewer asks a series of questions to get answers on what the background of the coastal communities involved in the management of village fund and determining factors influence their participation. In gathering the data is processed, interviews and focus group discussions were audio recorded and transcribed verbatim. To ensure reliability of data, one of the researchers listened to every recording while following the transcript to check for errors in transcription (Gibbs, 2007). There are no obstacles in the process of transcription.

Data was coded method following Saldana (2016) are two cycle coding process allowing codes to emerge from data or information collected in interviews and in-depth interviews. Two members of the research team were involved in the coding process. A qualitative analysis was established within the software (CAQDAS) to maximizing coding definitions and coherence between codes (Guest, MacQueen \& Namey, 2012). Once codes were established and agreed upon, two interviews were chosen and coded by each member of the team and then met to cross-check the codes to reach intercoder agreement (Creswell, 2014). In process coding, to ensure the validity of the data, the members of research obtained regularly meetings to cross-check cooding.

\section{RESULTS}

Informants were asked to describe their participation in village fund management and also to discuss strategies that enhanced participation. Through the analysis of interview and in-depth interview, the theme of "social capital" emerged. Among the data, there were references from both coastal communities.

The success of a development program can only be effective when all stakeholders can participate from the programming to the monitoring and evaluation of programs. In this study explores the coastal community involvement in the management of village fund in Takalar. Communities as stakeholders have a right to participate in the village fund management, so as to have a pragmatic and moral justification to participate in participating to support the successful development program funded through the village fund. The following will describe the results of research, ranging from the participation of coastal communities in the management of village funds. People who living in coastal areas have a social capital that can be developed to increase their participation in the management of village funds so as to create accountability.

\subsection{Participation in Village Fund Management}

Participation of coastal communities in the management of funds is a form or way of taking part to become subject or actors in the coastal village development. The village community can participate in three aspects, (1) on the planning of the development referred to musrenbang, (2) execution or implementation of the program, and (3) the control or supervision of the planning and implementation of programs funded by the village fund budget. Of these three aspects, the form of participation can be shaped; energy, thoughts, facility or equipment and the ability or expertise in certain subject.

The planning of rural development programs (Musrenbang) is planning forum (program) is implemented by public institutions, namely the village government, in cooperation with citizens and other stakeholders. Musrenbang meaningful will be able to develop an understanding of the importance and progress of the village, by scanning the potential and development resources that are not available either from within or outside the village. Musrenbang a meeting forum of citizens and various stakeholders to present the result "analysis of emergency/vulnerability village", discussed the draft Government Work Plan (GWP) of building the village, agree on priority actions including budget allocation. One coastal resident who participated in planning forums suggests:

An active participation, not about the presence, even though it was the first step. Active participation involving all ideas and concepts that consider the needs of the community. Because it is the first step of participation is not symbolic but constructed of consciousness is to involve the community in the village meetings, involving the preparation of the program and budget, enter the program required by the community in the GWP (Informant No.1)

Some citizen spoke positively of the experience they are involved in Musrenbang. Their involvement in the planning of the program will foster a sense of belonging to the program will be implemented. They say that: 
Since we were planning, then in practice we want to make the program a success. We contribute to maintain what we have done. (Informant No. 2).

Involving the community in Musrenbang is to involve the community in decision-making processes. Basically everyone has the skills, ability and initiative as well as the right to use the initiative and be involved in every process of development.

\subsection{Strategies to Enhance Community Participation}

\section{Strengthening Public Trust}

Trust an indicator of the success of a relationship, both in the family and in community relations as relations between the government and the people. Trust the people did not appear suddenly. However, many factor that can increase public trust. Public trust can be increased if the government manages development programs accountable.

We must change. We must be transparent to the community, to respond to these grievances, dare to be responsible. By doing so, public trust in government will increase the resources that must be met in improving confidence in the government is a human, regulatory, and good democratic system. Currently, progress not only dependent on the community but also elite. If the elite have a strong political will to build a community, then automatically the people will believe in them. This can be evidenced by the real work, which can be seen by the public. Not just a political promise only when the head of the village, but it must be proved once elected (Informant No. 2)

Public trust can also be increased if the village head has a close emotional connection with them. It is as stated by a village head following:

We give priority to community participation in building the village, that with my background which is close to the people, I was able to improve public trust. Together citizens improve infrastructure such as footpaths, breakwaters, and improve public facilities, and transparence for all the policies which I take to the public (Informant No. 3)

On the other hand, there are also people who found the village head must be accountable for all funds that have been used for village development. So not only had an emotional closeness (a close friend or family) but also must be able to account for the entire budget of the village fund so that people can know well.

The village heads should be ready to present its accountability towards village funds that have been granted some time ago. Thus, we can have more trust to the government (Informant No. 5).

In building a synergy of government, it takes a few things that should be mutually supportive. Starting from the political elite to the community must come together to make it happen.

We have to try to change and get out of all this. We must be transparent to the public, to respond to all complaints, dare to be responsible, and to enhance community participation. Besides, we should account for village funds that have been granted some time ago. Therefore, the public trust in government increases (Informant No. 5)

Based on the above description can be concluded that the strategy used by the village government to increase public participation is to increase public trust through transparency and accountability of village funds.

\section{Strengthening Sense of belonging}

The Village fund program which has been imposed by the Indonesian government since 2015 aims to increase the independence of the village. Therefore, the management handed over entirely to the villagers, from planning, organizing, implementing, and monitoring the village fund program. By giving full authority to the community it will increase the sense of belonging to the village fund program.

Village Head revealed during the public be involved in managing the village fund. The proof, development activities both physical and non-physical can't be separated from the role of the community. All of society is growing awareness 
and responsibility to nurture the development program without any coercion from anyone, so that the existing village funds can meet their needs in building the village.

Here is an excerpt statement by a citizen who is involved in the management of village fund says:

we realize with all my heart that the village fund program is for the benefit of us, then we are obliged to succeed in this program. This program was ours. Therefore we voluntarily want to work together to implement each activity (Informant No. 4)

Very high public participation in the implementation of the village fund program because most of the villagers consider the village as part of his home. Where they were born and bred. Since childhood, they live together, interact together, and grow together. The nature of the family has been growing well.

\title{
Strengthening Solidarity
}

Another aspect raised to improve public participation is solidarity. Solidarity is a condition of the relationship between individuals and / or groups that are based on moral feelings and beliefs that are shared and reinforced by shared emotional experience. Solidarity emerged among the public when the program to be implemented concerning their interests. This will encourage them to participate in development programs. For example, when the village government will build a footpath to connect their village that had been badly damaged, people feel that this program is very good for their interests. Society willingly helped. There is help in the form of personnel and others who helped prepare food for the workers. They participated worked together to build the road which they desperately need. Some citizens expressed their solidarity experience in the development program. For one citizen, their solidarity experience had been more conductive to participation building.

Another form of solidarity that emerged in the rural development program is solidarity among fellow women to fight for the rights of gender equality. They voluntarily came to the Musrenbang forum to voice their rights in women empowerment programs, such as labor-intensive programs to improve women's skills to help improve the welfare of the family.

\begin{abstract}
We came to Musrenbang as women representatives to voice our rights in the development program. I came together the other female friends, when I came by myself, then our voice is less heard. I see a lot of potential in this coastal area that can be managed by women, such as seaweed as one fishery potency. Seaweed can be processed into various products of high economic value. However, because we do not have enough skill to it, so we hope that the community empowerment program can be made a training activity seaweed processing (FGD 3)
\end{abstract}

The above statement shows that women have a strong desire to help her husband earn a living to meet their basic needs. The desire foster a sense of solidarity among them to struggle to get their rights to obtain employment. There is a strong awareness within them to become independent. Sense of community or solidarity that grows in the community should be seen as a valuable social capital in rural development. Therefore, the government can take advantage of the potential of social capital in the implementation of development programs.

\section{DISCUSSION AND CONCLUSION}

The objective of rural development is to improve the welfare of people directly and indirectly is to lay the foundations of a solid to strengthen the development of regional and national development. To accelerate the growth of the village, the village government should seek to foster the participation of rural communities. According Schlippe (2007), a village can grow well there are three elements that constitute a unity, the village, the community, and village administration. In public participation, implementation of development programs needed awareness of citizens will be of interest and the same interests. For the success of the program, residents are required to be involved not only in terms of ideas but also the emotional engagement. Strategies that can be applied is to raise public awareness.

Public trust in government, the increasing solidarity and a sense of belonging are the social capital that can increase community participation in the development programs run by the government. Governments must be able to demonstrate their responsibility in earnest so that the public trust. Doing program with transparent and accountable is one way to increase public trust in government. 
Trust, a belief in the credibility of a person or system, associated with different outcomes or events, which express a belief that faith on the integrity or the love of others, or the accuracy of abstract principles (technical knowledge). The value is understood as the idea of whether a meaningful experience, precious, valuable and inappropriate or meaningless, worthless, worthless and inappropriate. Value hooked up with ideas that are shared about something is good or bad, it is expected or not expected (Damsar, 2009).

In line with the concept of solidarity and participation in the management of village fund, Emile Durkheim (18581917) in developing a sociological theory argue that social solidarity is a state of the relationship between individuals and/or groups that are based on moral feelings and beliefs that are shared and reinforced by experience emotional together. Solidarity emphasized on the state of relations between individuals and groups and the underlying attachment along in life with the support of the moral values and beliefs that live in the community. Concrete manifestation of the joint relationship will bear the emotional experience, thereby strengthening the relationship between them. Thus, the emerging solidarity among members of society, the voluntary participation will be easily realized.

One form of solidarity that emerged in this study are of mutual cooperation, mutual assistance term refers to activities or help each other to help each other in society. This is reflected in the lack of cooperation of mutual help in implementing the road construction program. Most people work to build roads, while others help prepare food for the workers or laborers. This is in line with the views Nasution (2009) that reflect the tradition of solidarity of cooperation in various fields of activities in community activities such as building houses, repair of public facilities, etc. Cooperation could grow if people have an emotional attachment to each other. The proximity of a person to a person, an individual with a group, or a group to group social interaction can foster a mature and positive in promoting economic growth, social, educational, and cultural (Susanti, et al., 2015).

In addition to mutual cooperation, forms of social solidarity that emerged in this study is the concern of fellow women to fight for their rights training seaweed processing. Form of awareness among fellow women is based on the moral equation, the same collective, and beliefs held and strengthened by the emotional experience. the principle of social solidarity include: mutual aid, mutual caring, sharing, and collaboration in support of rural development in both financial and personnel and so on.

Dynamic aspect of social capital is the ability to move. Social capital is understood as an investment can enlarge, shrink, remain or even disappear within a structure of social relations. All social resources (networks, trust, values and norms) owned contains a power move social investment to be larger or smaller. The strength of the move appears when social capital is used in a structure of social relations. The appearance is evident from the extent of social investment that has grown to achieve its objective of individual and / or group efficiently and effectively with the other capital. The more frequent use of social capital, then it will develop (grow) and vice versa if it is not used, it will diminish or fade.

Although it is generally understood that the erosion of social capital because of the presence of the state and the market (Fukuyama, 2000). On the other hand, Arthurson, at all (2014) has found that social capital is understood as a concept that can be used to guiding policy development and program delivery. Unlike the debate on Bancin (2005) which says that the state actually can strengthen social capital in the community if the state has the will to guide towards autonomy that empowers coastal communities, the creation of a local environment that is conducive to coastal communities with the community and improve the quality of education of coastal communities. In addition, local governments should be able to foster a sense of belonging within the community towards development programs are implemented. With the increasing sense of belonging, it would increase participation (Thomas, at all, 2014). They recognize that the full authority given to them will increase the sense of belonging to the village fund program.

Participation is the active involvement of a person, or a group of people (society) consciously to contribute voluntarily to development programs and be involved from the planning, implementation, monitoring until the evaluation stage. The public will trust the development program if they feel involved in the process of planning and implementation, because they will know the process of the program and will have a sense of belonging to the program. Moreover, by involving the community means giving democratic rights of society itself

Social capital such as kinship, public confidence in the organizers of the program, people felt needed energy and thoughts in the process of planning, implementation and evaluation of the program, would increase the effectiveness of development programs implemented in the villages on the coast. Investments or social capital is social resources such as trust, networks, values, norms and sense of belonging. Static aspect of social capital is social resources, while the dynamic aspect is the power of moving. 


\section{REFERENCES}

- Arthurson, K., Fran B., \& Anna Z. (2014). Exploring Social Capital: as Concept and Practice in Australian Public Health Policies and Programs. Australian Journal of Public Administration, Vol. 73 (1), 79-97. March.

- Bancin, Mhd Bahrun, (2005). Dynamics of Social Capital Coastal Communities In Management of Coastal and Ocean Resources (Case Study on the Coastal Villages Asahan). Thesis, Graduate School, Institut Pertanian Bogor.

- Bingham, L.B., Tina, N., \& Rosemary O. (2005). The New Governance: Practices and Processes for Stakeholder and Citizen Partisipation in the Work of Government. Public Administration Review, 65 (5), 547-558. Sep/Oct.

- Brinkerhoff, D.W. \& Benjamin L. C., (2002). Managing Policy Reform: Concepts and Tools for Decision-Makers in Developing and Transitioning Countries. Bloomfield, CT: Kumarian Press, Inc.

- Cresweell, John W. (2014). Research Design Qualitative, Quantitative, and Mixed Methods Approaches. Thausand Oaks, CA: Sage Publications.

- Damsar. (2009). Introduction to Sociology Economy, Jakarta: Kencana Prenata Media Group.

- Guest, G., MacQueen, K. M., \& Namey, E. E. (2012). Applied Thematic Analysis . Thousand Oaks, CA: Sage

- Malvicini, Cindy F and Sweetser, Anne T., (1999). Annual Report, Asian Development Bank, Technical Assistance to Help Smooth Capacity Building and Participatory Activities II. Manila.

- Nasution, Z. (2009). Social Solidarity and Public Participation in Rural Transition. Malang: UMM Press.

- Fukuyama, F. (2000). Social Capital and Civil Society. International Monetary Fund Working Paper, WP/00/74, 1-8. Foundation of Social Capital. Publishing Limited. http://www.imf.org/external/pubs/ft/wp/2000/wp0074.pdf

- Putnam, R.D. (1993). The Prosperous Community: Social Capital and Public Life. American Prospect. Spring. 1995. Bowling Alone: America's Declining Social Capital.

- ------------ (1993). Making Democracy Work: Civic Traditions in Modern Italy. Princeton University Press, Princeton.

- Pratikno, at all. (2001). Penyusunan Konsep Perumusan Pengembangan Kebijakan Pelestarian Nilai-Nilai Kemasyarakatan (Social Capital) Untuk Integrasi Sosial. Tim Peneliti Fisipol UGM.

- Roberts, N. (2004). Public Deliberation an Age of Direct Citizen Participation. American Review of Public Administration, 34 (4), 315-353. December, Sage Publication. doi:101.1177/0275074004269288.

- Saldana, J. (2016). The Coding Manual for Qualitative Researchers (p. 369). Third Edition, Sage Publications, Ltd.

- Susanti, Henny and Sismudjito, (2015). Muslim Socfindo (Brotherhood Bonding Functions In Building Social Relations With Local Communities. Perspektif Sosiologi, Vol. 3, NO. 1, October, pg. 75-89.

- Thomas, L., J. Herbert, \& M. Teras. (2014). A Sense of Belonging to Enhance Participation, Succes and Retention in Online Programs. The International Journal of the First Year in Higher Education. Vol. 5 (2), pp. 69-80.

- Weiss, R. S. (1995). Learning from Strangers: The Art and Method of Qualitative Interview Studies (p. 256). New York, NY: Free Press.

- Woolcock, M., (2001). The Place of Social Capital in Understanding Social and Economic Outcome, Canadian Journal of Policy Research, 2 (1) : 1-27. 